\title{
INCIDENCE OF GREEN SOYBEAN SEEDS AS A FUNCTION OF ENVIRONMENTAL STRESSES DURING SEED MATURATION ${ }^{1}$
}

\author{
GILDA PIZZOLANTE DE PÁDUA², JOSÉ DE BARROS FRANÇA-NETO³, MARIA LAENE MOREIRA DE CARVALHO4, \\ FRANCISCO CARLOS KRZYZANOWSKI ${ }^{5}$,RENATO MENDES GUIMARÃES ${ }^{6}$
}

\begin{abstract}
Hot and dry weather conditions during soybean [Glycine max (L.) Merrill] seed maturation can cause forced maturation of the seed, resulting in the production of high levels of green seed, which may be detrimental to seed germination. These stressful conditions were imposed on soybean plants during seed maturation to investigate the production of green seeds and seed quality. Plants of the CD 206 cultivar were grown in a greenhouse until the $\mathrm{R}_{5.5}$ growing stage and then transferred to phytotrons at $\mathrm{R}_{6}$ and $\mathrm{R}_{7.2}$ for stress induction. Plants were subjected to two temperature regimes, high $\left(28^{\circ} \mathrm{C}\right.$ to $\left.36^{\circ} \mathrm{C}\right)$ and normal $\left(19^{\circ} \mathrm{C}\right.$ to $\left.26^{\circ} \mathrm{C}\right)$, and four soil water availability conditions, control (adequate water supply), 30\% gravimetric moisture (GM), 20\% GM and no water supply. Seed were harvested at $\mathrm{R}_{9}$. Green seed percentages and 100-seed weights from the lower, middle and upper thirds of each plant were determined. Seed quality was assessed by germination, tetrazolium (viability and vigor) and electrical conductivity tests. Occurrence of green seed varied from $9 \%$ to $86 \%$, depending on the severity of the stresses imposed. High temperature, coupled with no water supply at $\mathrm{R}_{6}$, resulted in a pronounced occurrence of green seeds. There was no difference in the percentage of green seeds among the plant segments. Seed quality was negatively affected by the incidence of green seeds. A procedure for screening soybean genotypes in a phytotron for their tolerance and/or susceptibility to the production of green seeds was developed.
\end{abstract}

Index terms: Glycine max, seed quality, temperature stress, water stress

\section{INCIDÊNCIA DE SEMENTE VERDE EM FUNÇÃO DO TIPO DE ESTRESSE DURANTE A MATURAÇÃO DA SEMENTE DE SOJA}

\begin{abstract}
RESUMO - Condições climáticas desfavoráveis, principalmente na região Central do Brasil, durante o período de maturação da soja, têm ocasionado o aparecimento de semente de soja verde. Essa incidência, em condições de campo, pode variar em função de aspectos como a época de ocorrência ou o tipo de estresse a que as plantas são submetidas. Os objetivos desta pesquisa foram: verificar em qual estádio de desenvolvimento da planta a imposição de estresses de temperatura e deficiência hídrica propicia maior ocorrência de semente verde, e observar a variação dessa ocorrência em diferentes partes da planta e seus efeitos sobre a qualidade fisiológica de sementes de soja. Sementes da cultivar CD 206 foram produzidas em casa de vegetação permanecendo até o estádio de desenvolvimento $\mathrm{R}_{5.5^{\circ}}$. Na fase final de maturação da soja, nos estádios $\mathrm{R}_{6}$ e $\mathrm{R}_{7.2}$, as plantas foram transferidas para
\end{abstract}

\footnotetext{
${ }^{1}$ Submetido em 18/08/2009. Aceito para publicação em17/09/2009. Parte da Tese de Doutorado do primeiro autor apresentada a UFLA.
}

${ }^{2}$ Eng. Agr., Dra. Pesquisadora da Embrapa/EPAMIG, Caixa Postal 351, CEP 38.001-970. Uberaba - MG. gpadua@epamiguberaba.com.br

${ }^{3}$ Eng. Agr., Dr. Pesquisador da Embrapa Soja, Caixa Postal 231, CEP 38.001-970. Londrina - PR.jbfranca@cnpso.embrapa.br
${ }^{4}$ Eng. Agr., Dra. Professora do Departamento de Agricultura, UFLA, Caixa Postal 3037, CEP 37.200-000. Lavras - MG. mlaenemc@ufla.br

${ }^{5}$ Eng. Agr., Dr. Pesquisador da Embrapa Soja, Caixa Postal 231, CEP 38.001-970. Londrina - PR.jck@cnpso.embrapa.br

${ }^{6}$ Eng. Agr., Dr. Professor do Departamento de Agricultura, UFLA, Caixa Postal 3037, CEP 37.200-000. Lavras - MG. renatomg@ufla.br. 
câmaras de crescimento (fitotrons), para a indução de estresse térmico, com temperaturas elevadas (variações de $28^{\circ} \mathrm{C}$ a $36^{\circ} \mathrm{C}$ ) e temperaturas amenas (variações de $19^{\circ} \mathrm{C}$ a $26^{\circ} \mathrm{C}$ ). Para o estresse hídrico, a quantidade de água nos vasos foi controlada nos seguintes níveis: testemunha (suprimento adequado de água); 30\% de umidade gravimétrica (Ug); 20\% de Ug; e sem água (corte total de irrigação). A qualidade da semente, colhida no estádio $\mathrm{R}_{9}$, foi avaliada pelos testes de germinação, tetrazólio e condutividade elétrica. Determinou-se, ainda, o peso de 100 sementes e a porcentagem de semente verde em diferentes posições na planta. A porcentagem de ocorrência de semente verde variou de $9 \%$ a $86 \%$ em função da variação de umidade e de temperatura. A imposição de estresses de elevada temperatura e corte total de irrigação, no estádio de desenvolvimento $\mathrm{R}_{6}$, propiciaram acentuada ocorrência de sementes verdes. Estresse hídrico intenso ( $20 \%$ de Ug e corte total de irrigação) em $\mathrm{R}_{6}$ e $\mathrm{R}_{7.2}$, quando associado com temperaturas amenas, não resulta na ocorrência de índices significativos de semente verde. Não existem variações de ocorrência de semente verde nas diferentes partes da planta, no que se refere a sua posição nos terços inferior, médio e superior. A qualidade fisiológica de sementes de soja é afetada negativamente pela incidência de semente verde. Com base nos resultados do presente trabalho, foi desenvolvida metodologia em fitotron, visando a seleção de genótipos de soja quanto à sua tolerância ou suscetibilidade à produção de sementes esverdeadas.

Termos para indexação: Glycine max, estresse hídrico, estresse térmico, qualidade fisiológica

\section{INTRODUCTION}

The quality of soybean seed, particularly in tropical and subtropical regions, can be influenced by several factors occurring before and during harvesting and at the other production stages. Such factors include drought periods, insect damage, temperature extremes during maturation and severe fluctuations in environmental moisture conditions, which accelerate the seed deterioration process (FrançaNeto et al., 2000).

Degenerative changes in the seed, mainly after the onset of physiological maturity, are caused by alternating dry and moist period conditions associated with high temperatures at the end of maturation. Deterioration caused by weathering is directly related to seed exposure to such alternating conditions, so that the physiological quality is maintained or decreased depending on the environmental conditions preceding harvesting (McDonald Jr., 1975).

Adverse weather conditions during seed filling and maturation in soybean result in forced seed maturation, which is associated with low yields and the occurrence of green seed, leading to a substantial decrease in quality and a significant reduction in the crop productivity (França-Neto et al., 2005). The occurrence of these expressive levels of this problem had been reported in China (Theanjumpol,
2002), in tropical regions of Brazil (Zorato et al., 2007; França-Neto et al., 2005), in several regions near Ontario in Canada, and in the Kansas region in the U.S.A. (Bohner, 2002).

High temperature is considered the main cause of forced seed maturation in soybean (França-Neto et al., 2005). Studies have suggested that increase in temperature to over $30^{\circ} \mathrm{C}$ during the period of dry matter transference from the plant to the seed can cause serious damage to seed production and quality. Under this condition, reserves are rapidly translocated to the seed, preventing the complete degradation of the chlorophyll and promoting green seed production of low quality and reduced performance (Marcos Filho, 2005).

Chlorophyll degradation is initiated during senescence by endogenous factors and may also be influenced by external factors, such as water stress, light reduction, temperature variation and increased ethylene content. These factors interfere in the normal process and cause chlorophyll degradation to accelerate or retard (Heaton and Marangoni, 1996; Takamiya et al., 2000).

Although the conversion of chlorophyll into its derivatives is important in ripening soybean, the mechanisms responsible for the physiological degradation of this pigment in the seed during maturation, as well as the causes 
and effects of the occurrence of green or yellowish-green seed in soybean, are largely unknown. Thus, the objective of this study was to evaluate the occurrence of green seed in plants subjected to heat and water-deficit stresses and to observe the variation in this occurrence in different parts of the plant and its effects on the physiological quality of soybean seed. Additionally, this research aimed to develop a methodology in a phytotron to screen soybean genotypes with regard to their tolerance and/or susceptibility to the expression of green seed.

\section{MATERIALS AND METHODS}

\section{Plant materials}

Seed of the soybean cultivar CD 206 were produced in greenhouse conditions at Embrapa Soybean, in Londrina, Brazil. The seed quality analyses were carried out at the seed testing laboratories of Embrapa Soybean and of the Federal University of Lavras, in Lavras, Brazil.

\section{Stresses induction}

Temperature- and water-related stresses were induced during maturation in soybean plants at two growth stages, as described by Ritchie et al. (1994): $\mathrm{R}_{6}$ (full seed and green leaves) and $\mathrm{R}_{7.2}$ (from $51 \%$ to $75 \%$ yellow leaves and pods). Potted plants were watered daily in a greenhouse until $R_{6}$ and $R_{7.2}$, when they were transferred to growth chambers (phytotrons) until the seed reached maturity at $\mathrm{R}_{9}$.

\section{Temperature stress}

Two phytotrons were used to induce temperature stress, one set at high temperatures $\left(28^{\circ} \mathrm{C}\right.$ from 5:00 p.m. to 8:00 a.m.; $32^{\circ} \mathrm{C}$ from 8:00 to $10: 00$ a.m.; $36^{\circ} \mathrm{C}$ from 10:00 a.m. to 2:00 p.m.; and $32^{\circ} \mathrm{C}$ from 2:00 to 5:00 p.m.); and the other set at mild temperatures $\left(19^{\circ} \mathrm{C}\right.$ from $5: 00 \mathrm{pm}$ to 8:00 a.m.; $24^{\circ} \mathrm{C}$ from 8:00 to $10: 00$ a.m.; $26^{\circ} \mathrm{C}$ from 10:00 a.m. to 2:00 p.m.; and $24^{\circ} \mathrm{C}$ from 2:00 to 5:00 p.m.), with a 12.5-h photoperiod (from 7:00 a.m. to 7:30 p.m.).

\section{Water stress}

Water stress was induced under four soil water availability conditions imposed in the pots: control (with a daily water supply of $1.0 \mathrm{~L}$ per pot); $30 \%$ soil gravimetric moisture (GM); $20 \%$ GM; and no water (with no irrigation water applied). The soil gravimetric moisture was determined based on the relationship between the mass of water in a soil sample and the dry mass of that sample
(Claessen, 1997). On a daily basis, the pots were weighed and the soil moisture content adjusted accordingly.

\section{Harvest}

The seeds were harvested at the $R_{9}$ stage, point of harvest maturation. Seed were hand thrashed from each plant individually and the percentage of green seed and weight of 100 seeds on the lower, middle and upper thirds of the plant were recorded. Following these determinations, the seed obtained from the each third were grouped and subjected to the following tests.

\section{Germination tests}

Carried out with four sub-samples of 50 seeds per experimental unit, which were placed in rolled paper towel moistened with water added at the proportion of 2.5 times the dry paper weight and kept in a germinator at $25^{\circ} \mathrm{C}$. Seedlings were evaluated at five days after sowing, according to the Brazilian Rules for Testing Seeds (Brasil, 1992), and the results expressed as percentage of germination.

\section{Tetrazolium tests}

Carried out with two sub-samples of 50 seeds per experimental unit, which were preconditioned on paper towel moistened with water, added at the proportion equivalent to 2.5 times the dry paper weight, at $25^{\circ} \mathrm{C}$, for $16 \mathrm{~h}$. Seed were stained in a $0.075 \%(\mathrm{w} / \mathrm{v})$ solution of 2,3,5-triphenyl-tetrazolium chloride, at $40^{\circ} \mathrm{C}$ in darkness, for $2.5 \mathrm{~h}$. After staining, the seeds were washed in running water and subsequently classified for vigor, viability, and different types of damage, according to methodology by França-Neto et al. (1998).

\section{Electrical conductivity tests}

Carried out with four sub-samples of 50 seeds from the pure seed fraction per experimental unit. Seed were weighed and soaked in disposable plastic cups containing $75 \mathrm{~mL}$ deionised water and incubated at $25^{\circ} \mathrm{C} \pm 1{ }^{\circ} \mathrm{C}$ for 24 h (AOSA, 1983). The conductivity of the soak water of each sample was measured, divided by the seed weight and expressed as $\mu \mathrm{S} \cdot \mathrm{cm}^{-1} \cdot \mathrm{g}^{-1}$.

\section{Statistical analysis}

In the first phase of the experiment, in which the plant thirds were examined, a randomized complete design was used with a $4 \times 2 \times 3$ factorial arrangement (four levels of water supply; two stages of development; three thirds of the plant), at high and mild temperatures, for the variable 
percentage of green seed, with six replications per treatment, and depicted by Box plots.

After grouping the plant thirds, the second phase of the experiment was performed in a randomized complete design with a $4 \times 2 \times 2$ factorial arrangement (four levels of water supply; two temperature regimes; two stages of development), with three replications, for all the other variables. The data were subjected to analysis of variance and the means were compared by the ScottKnott cluster analysis, at 5\% level of significance. All statistical analyses were performed using the $\mathrm{R}^{\circledR} \mathrm{v} 2.1 .1$ $(\mathrm{R}, 2005)$ and SISVAR $^{\circledR}$ v4.3 (Ferreira, 2000) statistical programs.

(a)

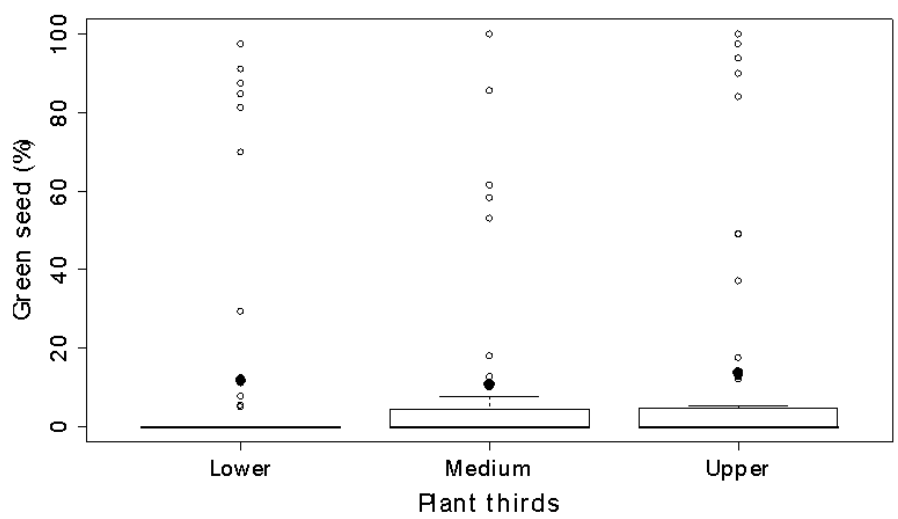

\section{RESULTS AND DISCUSSION}

Data are presented in graphs depicted by Box plots. They are represented by the lower limit of the box, where there are $50 \%$ of the data, and by the upper limit, with $75 \%$ of the data. The mean is represented by the dot inside the Box plots and the mode by the internal line. The line above and below the Box plots represents the total range of the data and the dots above this line are the outliers. There was little variation in the occurrence of green seed from the lower to the upper third of the plant, in which the mean occurrences were $11.9 \%$ for the lower third, $10.8 \%$ for the middle, and $13.6 \%$ for the upper third (Figure 1a).

(b)

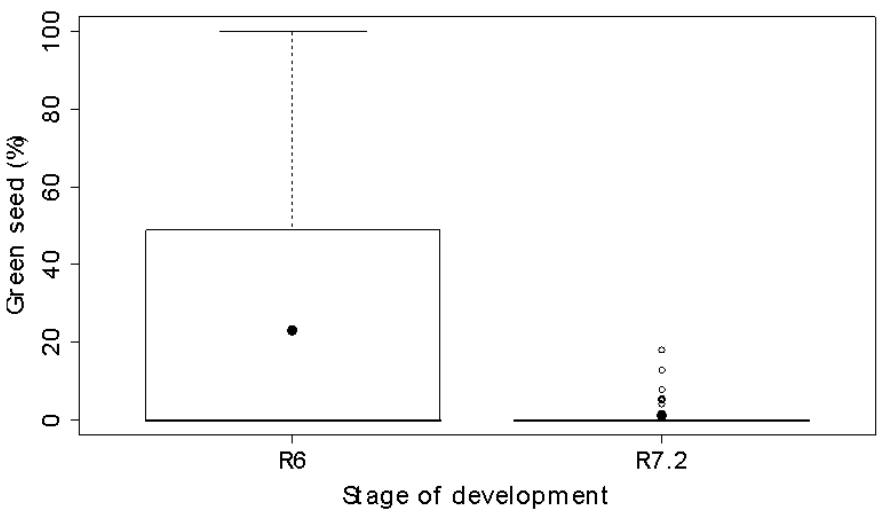

(c)

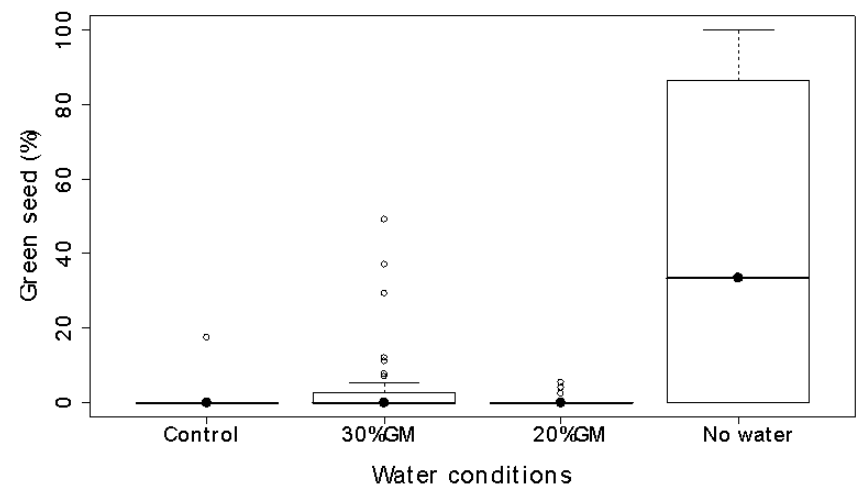

FIGURE 1. Occurrence of green seed (\%) in soybean plants, cv. CD 206, as a function of water-deficit (control, $30 \%$ GM, $20 \%$ GM, no water) and heat stresses $\left(28^{\circ} \mathrm{C}\right.$ to $\left.36^{\circ} \mathrm{C}\right)$, according to the seed position on the plant (a), to the developmental stage (b) and to the conditions of soil water availability (c). Graphics depicted by Box-plots, where the mean is represented by the dot inside the Box plots and the mode by the internal line. The line above and below the Box plots represents the total range of the data and the dots above this line are the outliers. 
Seed development depends on the supply of photoassimilates and thus it was expected that it might be influenced by the position of the seed on the parent plant. Seed developing on the lower part of the plant may receive assimilates from shaded leaves, which

(a)

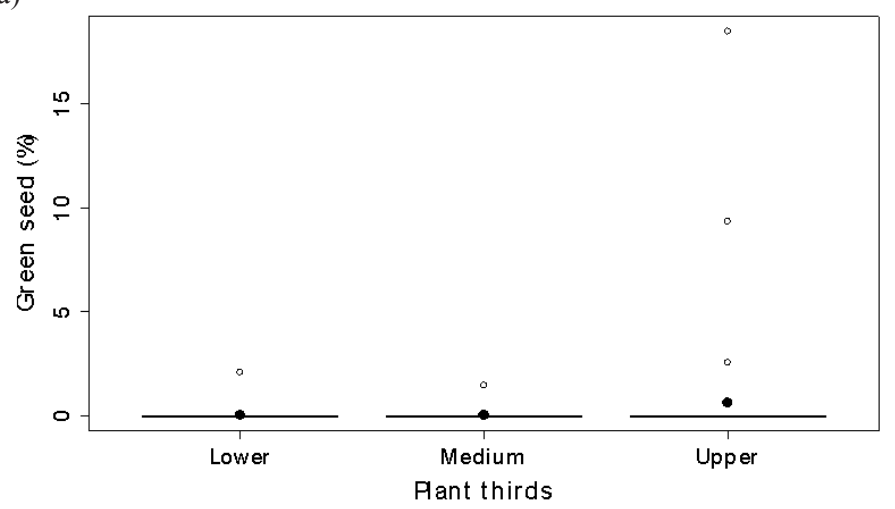

probably have lower photosynthetic rates (Marcos Filho, 2005). In the present study, however, there was no significant variation in green seed expression among the lower, middle and upper thirds of the plant (Figures 1a and $2 a)$.

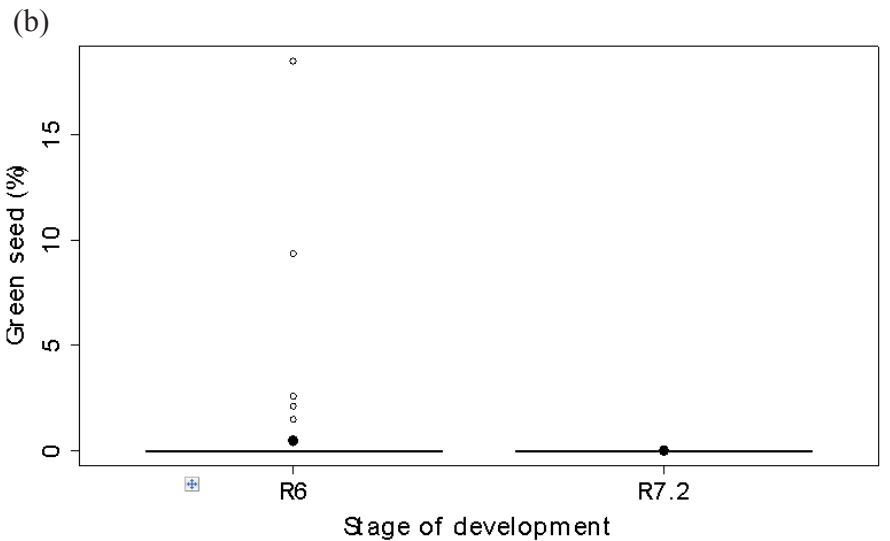

(c)

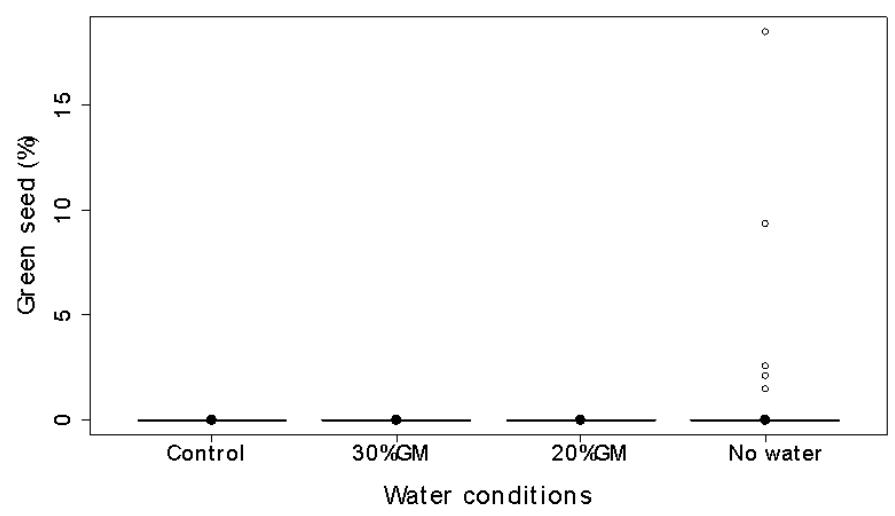

FIGURE 2. Occurrence of green seed (\%) in soybean plants, cv. CD 206, as a function of water stress (control, $30 \%$ GM, $20 \%$ GM, no water) and normal temperature $\left(19^{\circ} \mathrm{C}\right.$ to $\left.26^{\circ} \mathrm{C}\right)$, according to the seed position on the plant (a), to the developmental stage (b) and to the conditions of soil water availability (c). Graphics depicted by Box-plots, where the mean is represented by the dot on the line and the data above this line are the outliers.

Following induction of heat and water-deficit stresses in plants at $\mathrm{R}_{6}$ and $\mathrm{R}_{7.2}$, the percentages of green seed were determined and are presented in Figure 1(b). The stresses resulted in a pronounced occurrence of green seed of up to $100 \%$, when imposed at $\mathrm{R}_{6}$. Most of the observed data were below 50\%, which are represented in the Box-plots, with a mean value of $23 \%$, as identified by a dot inside the Box plots, while at $\mathrm{R}_{7.2}$ the mean percentage was about $1 \%$. It is worth noting that stress induction at $\mathrm{R}_{6}$ led to an increase in green seed occurrence. According to Sinnecker (2002), the chlorophyll content in soybean seed at $\mathrm{R}_{6}$ is relatively high, while it is almost completely degraded between this stage and physiological maturity and only residual amounts remain. From $\mathrm{R}_{6}$ onwards, imposed water- and temperaturerelated stresses do not result in high green seed occurrence (Figure 1b).

Figure 1(c) shows that there was almost no occurrence of green seed under adequate soil-water supply and with $30 \%$ 
GM. A mean percentage of $5 \%$ was obtained with $20 \%$ GM, whereas no water supply resulted in an increased incidence of green seed ( $86 \%)$ with a mean occurrence of $43 \%$. Thus, severe water stress, associated with high temperatures $\left(28^{\circ} \mathrm{C}\right.$ to $36^{\circ} \mathrm{C}$ ), led to a high incidence of green seed in soybean plants.

The incidence of green seed was considerably lower when the plants were subjected to water-related stresses under normal temperature condition (Figures 2a, 2b, 2c), with mean values equal, or nearly equal, to $0 \%$. These results were similar to the findings of Costa et al. (1994) who demonstrated that mild temperatures $\left(<22^{\circ} \mathrm{C}\right)$ during seed maturation favoured the production of seed with good physiological and health qualities. These authors related the presence of green seed in lots to poor seed physiological quality.

In a second phase of analyses, after grouping the seeds from the three thirds of the plant, it was observed that the interaction between temperature and development stage of the plant was significant for all variables. This fact was also observed for the temperature and water availability condition interaction, except for 100 -seed weight. However, for the development stage and water availability condition interaction, no significant differences were observed for seed viability and weathering damage, as determined by the tetrazolium test. The triple interaction was significant only for electrical conductivity and for vigor determined by the tetrazolium test.

Based on the results shown in Table 1, the lowest germination percentage was obtained from seed at the $R_{6}$ stage subjected to heat stress that indicated that germination tended to increase with the progress of development. On the other hand, such behaviour was not observed at $\mathrm{R}_{7.2}$, under mild temperature condition. At this stage, in which the seeds were close to physiological maturity, there was no germination difference between the different temperature regime treatments. Physiological maturity is regarded as a reference point for determining the end of seed development (Marcos Filho, 2005). Accordingly, during this phase, the soybean plant is found to be less responsive to stress, as reported in studies by Dornbos and McDonald (1986).

Regarding the effects of water stress at $\mathrm{R}_{6}$, the highest germination percentages were obtained from seed under adequate soil-water condition, $30 \% \mathrm{GM}$ and $20 \% \mathrm{GM}$, while the lowest percentages were observed in plants given no water (Table 2). At the $\mathrm{R}_{72}$ stage, there was no significant difference in seed germination percentage among the conditions of soil water availability examined. The translocation of assimilates and dry matter accumulation in seed of soybean and other legume plants are intensified from the time at which the pods achieve their final length. Seed developing on plants exposed to water stress may not complete the same sequential events as those developing on non-stressed plants, and their composition might be affected at maturity (Egli, 1998). The results in Table 2 confirmed earlier findings by Dornbos and McDonald (1986) who reported that the critical period of reserve storage accumulation in soybean seed occurred between the $\mathrm{R}_{5}$ and $\mathrm{R}_{7}$ stages.

TABLE 1. Mean germination percentages of soybean seed obtained from plants subjected to high $\left(28^{\circ} \mathrm{C}\right.$ to $\left.36^{\circ} \mathrm{C}\right)$ and normal $\left(19^{\circ} \mathrm{C}\right.$ to $\left.26^{\circ} \mathrm{C}\right)$ temperatures at R6 and R7.2.

\begin{tabular}{ccc}
\hline \multirow{2}{*}{ Temperatures } & \multicolumn{2}{c}{ Developmental stages } \\
\cline { 2 - 3 } & $\mathrm{R}_{6}$ & $\mathrm{R}_{7.2}$ \\
\hline High & $92.1 \mathrm{bA}$ & $96.1 \mathrm{aA}$ \\
Normal & $98.3 \mathrm{aA}$ & $94.5 \mathrm{aB}$ \\
\hline
\end{tabular}

Means followed by the same capital letter on the line and by the same lowercase letter within a column are not significantly different $(\mathrm{P} \leq 0.05)$, as determined by the Scott-Knott test.

TABLE 2. Mean germination percentages of soybean seed obtained from plants subjected to different conditions of soil water availability (control, 30\% GM, 20\% GM, no water) at $\mathbf{R}_{6}$ and $\mathbf{R}_{7.2^{\circ}}$.

\begin{tabular}{ccc}
\hline \multirow{2}{*}{ Water levels } & \multicolumn{2}{c}{ Developmental stages } \\
\cline { 2 - 3 } & $\mathrm{R}_{6}$ & $\mathrm{R}_{7.2}$ \\
\hline Control & $97.0 \mathrm{aA}$ & $94.8 \mathrm{aA}$ \\
$30 \% \mathrm{GM}$ & $98.3 \mathrm{aA}$ & $93.8 \mathrm{aB}$ \\
$20 \% \mathrm{GM}$ & $95.3 \mathrm{aA}$ & $96.3 \mathrm{aA}$ \\
No water & $90.3 \mathrm{bB}$ & $96.2 \mathrm{aA}$ \\
\hline
\end{tabular}

Means followed by the same capital letter on a line and by the same lowercase letter within a column are not significantly different $(\mathrm{P} \leq 0.05)$, as determined by the Scott-Knott test.

Table 3 summarizes the results of vigor, as determined by the tetrazolium test, of seed obtained from different conditions of soil water availability, at high and normal temperatures, within each developmental stage examined. There was a significant effect of temperature regime on seed vigor and the seed subjected to normal temperature exhibited superior vigor levels at both stages of development and 
under all conditions of water supply tested. At $\mathrm{R}_{6}$, the highest vigor was obtained in seed of the control treatment and it declined with the increase in water-deficit stress. It is worth mentioning that, for the $\mathrm{R}_{72}$ development stage, there were no statistically significant differences in seed vigor between the water-stress-related conditions under both high and normal temperature regimes. At this stage, significant difference in seed vigor was detected only for the high temperature and no water supply treatments. The lowest seed vigor was recorded when stresses were imposed at $\mathrm{R}_{6}$ at high temperature and under soil water conditions of $30 \% \mathrm{GM}, 20 \% \mathrm{GM}$ and no water supply (Table 3 ). Therefore, at $\mathrm{R}_{7}$, the plant was less prone to drought, which has detrimental effects on seed production and quality.

TABLE 3. Mean vigor percentages, as determined by the tetrazolium test, of soybean seed obtained from plants subjected to different water supply levels at high $\left(28^{\circ} \mathrm{C}\right.$ to $\left.36^{\circ} \mathrm{C}\right)$ and normal $\left(19^{\circ} \mathrm{C}\right.$ to $\left.26^{\circ} \mathrm{C}\right)$ temperatures, within the stages of development.

\begin{tabular}{lcc}
\hline \multirow{2}{*}{ Treatments } & \multicolumn{2}{c}{ Temperatures } \\
\cline { 2 - 3 } & High & Normal \\
\hline $\mathrm{R}_{6}-$ Control & $91.3 \mathrm{aA}$ & $96.0 \mathrm{aA}$ \\
$\mathrm{R}_{6}-30 \% \mathrm{GM}$ & $83.3 \mathrm{bB}$ & $95.3 \mathrm{aA}$ \\
$\mathrm{R}_{6}-20 \% \mathrm{GM}$ & $81.0 \mathrm{bB}$ & $93.3 \mathrm{aA}$ \\
$\mathrm{R}_{6}-$ No water & $54.7 \mathrm{cB}$ & $90.7 \mathrm{aA}$ \\
$\mathrm{R}_{7.2}$ - Control & $88.7 \mathrm{aA}$ & $90.0 \mathrm{aA}$ \\
$\mathrm{R}_{7.2}-30 \% \mathrm{GM}$ & $84.0 \mathrm{aA}$ & $85.3 \mathrm{aA}$ \\
$\mathrm{R}_{7.2}-20 \% \mathrm{GM}$ & $88.0 \mathrm{aA}$ & $86.7 \mathrm{aA}$ \\
$\mathrm{R}_{7.2}$ - No water & $83.3 \mathrm{aB}$ & $90.0 \mathrm{aA}$ \\
\hline
\end{tabular}

Within each developmental stage, means followed by the same capital letter on a line and by the same lowercase letter within a column are not significantly different $(\mathrm{P} \leq 0.05)$, as determined by the Scott-Knott test.

Table 4 presents the seed viability results, as determined by the tetrazolium test, for the temperature $\times$ developmental stage interaction. The results were similar to those of the germination (Table 1) and vigor (Table 3) percentages, in which the lowest seed viability was found in the high temperature treatment at the $\mathrm{R}_{6}$ stage.

As seen in Table 5, seed at the $R_{7.2}$ stage were not influenced by the temperature regimes, according to the determination of weathering deterioration as detected by the tetrazolium test. However, a serious problem of weathering deterioration in seed subjected to heat stress was detected at the $\mathrm{R}_{6}$ stage that explained the results of the germination (Table 1) and viability (Table 4) tests. Costa et al. (2001) established the relationship between green seed incidence and the weathering deterioration index, demonstrating that, depending on the affected area of the seed, there will be a reduction in germination and vigor of seed lots.

TABLE 4. Mean viability percentages, as determined by the tetrazolium test, of soybean seed obtained from plants subjected to high $\left(28^{\circ} \mathrm{C}\right.$ to $\left.36^{\circ} \mathrm{C}\right)$ and normal $\left(19^{\circ} \mathrm{C}\right.$ to $\left.26^{\circ} \mathrm{C}\right)$ temperatures at the $\mathbf{R}_{6}$ and $\mathbf{R}_{7.2}$ stages of development.

\begin{tabular}{ccc}
\hline \multirow{2}{*}{$\begin{array}{c}\text { Developmental } \\
\text { stages }\end{array}$} & \multicolumn{2}{c}{ Temperatures } \\
\cline { 2 - 3 } & High & Normal \\
\hline $\mathrm{R}_{6}$ & $92.8 \mathrm{aB}$ & $98.5 \mathrm{aA}$ \\
$\mathrm{R}_{7.2}$ & $95.8 \mathrm{aA}$ & $95.7 \mathrm{bA}$ \\
\hline
\end{tabular}

Means followed by the same capital letter on a line and by the same lowercase letter within a column are not significantly different $(\mathrm{P} \leq 0.05)$, as determined by the Scott-Knott test.

TABLE 5. Mean percentages of weathering deterioration (TZ 6-8) of soybean seed obtained from plants subjected to high $\left(28^{\circ} \mathrm{C}\right.$ to $\left.36^{\circ} \mathrm{C}\right)$ and normal $\left(19^{\circ} \mathrm{C}\right.$ to $\left.26^{\circ} \mathrm{C}\right)$ temperatures at $R_{6}$ and $R_{7.2^{\circ}}$

\begin{tabular}{ccc}
\hline \multirow{2}{*}{$\begin{array}{c}\text { Developmental } \\
\text { stages }\end{array}$} & \multicolumn{2}{c}{ Temperatures } \\
\cline { 2 - 3 } & High & Normal \\
\hline $\mathrm{R}_{6}$ & $7.2 \mathrm{bB}$ & $1.5 \mathrm{aA}$ \\
$\mathrm{R}_{7.2}$ & $4.2 \mathrm{aA}$ & $4.3 \mathrm{bA}$ \\
\hline
\end{tabular}

Means followed by the same capital letter on a line and by the same lowercase letter within a column are not significantly different $(\mathrm{P} \leq 0.05)$, as determined by the Scott-Knott test.

The effects of environmental stresses, particularly those brought about by increased temperatures (Tables 4 and 5), can cause severe damage to seed quality. In this sense, Spears et al. (1997), working with soybean seed, demonstrated that increasing the temperatures of $27^{\circ} \mathrm{C}$ (daytime) and $22^{\circ} \mathrm{C}$ (night-time) to $33^{\circ} \mathrm{C}$ and $28^{\circ} \mathrm{C}$, respectively, led to reduced seed vigor. The most drastic consequences of adverse weather conditions include the accelerated seed deterioration rate and reduced viability. Environmental variations cause changes in cell membrane structure, lipid and protein degradations, as 
well as loss of ribosomes and reduced respiration capability (Woodstock et al., 1985) that affect seed germination and, consequently, seed quality.

The results of the electrical conductivity test (Table 6) showed the superiority of the seed subjected to mild temperature over those subjected to high temperature, at both development stages and under all conditions of water supply tested, as also reported for the seed vigor (Table 3). In the case of the $\mathrm{R}_{7.2}$ stage, the best electrical conductivity results were obtained in seed produced under mild temperature and adequate soil-water condition. Relating these values to those obtained in the tetrazolium test (vigor), it was observed that values within the range of $58-62 \mu \mathrm{S} \cdot \mathrm{cm}^{-1 \cdot g-1}$ corresponded well with high vigor, whereas values greater than $62 \mu \mathrm{S} \cdot \mathrm{cm}^{-1 \cdot g-1}$ tended to relate to seed of medium vigor. These results were similar to those reported by Vieira et al. (1991) who evaluated the effect of water stress on soybean seed germination and vigor. These authors reported values of electrical conductivity of 48 to $52 \mu \mathrm{S} \cdot \mathrm{cm}^{-1 \cdot g-1}$ for high vigor soybean seed lots. As for the $\mathrm{R}_{6}$ stage, no statistically significant difference was detected between the seed produced under adequate, $30 \%$ GM and 20\% GM soil conditions, under the high temperature regimen; however, this seed exhibited lower vigor when compared to those under the same conditions but subjected to the mild temperature regimen.

TABLE 6. Mean values of electrical conductivity $\left(\mu \mathrm{S} \cdot \mathrm{cm}^{-1} \cdot \mathrm{g}^{-1}\right)$ of soybean seed obtained from plants subjected to different water supply levels at high $\left(28^{\circ} \mathrm{C}\right.$ to $\left.36^{\circ} \mathrm{C}\right)$ and normal $\left(19^{\circ} \mathrm{C}\right.$ to $\left.26^{\circ} \mathrm{C}\right)$ temperatures, within the stages of development.

\begin{tabular}{crc}
\hline \multirow{2}{*}{ Treatments } & \multicolumn{2}{c}{ Temperatures } \\
\cline { 2 - 3 } & \multicolumn{1}{c}{ High } & Normal \\
\hline $\mathrm{R}_{6}$ - Control & $74.7 \mathrm{aB}$ & $59.3 \mathrm{aA}$ \\
$\mathrm{R}_{6}-30 \% \mathrm{GM}$ & $73.0 \mathrm{aB}$ & $56.0 \mathrm{aA}$ \\
$\mathrm{R}_{6}-20 \% \mathrm{GM}$ & $74.7 \mathrm{aB}$ & $60.7 \mathrm{aA}$ \\
$\mathrm{R}_{6}-$ No water & $122.3 \mathrm{bB}$ & $61.3 \mathrm{aA}$ \\
$\mathrm{R}_{7.2}-$ Control & $66.3 \mathrm{aB}$ & $58.3 \mathrm{aA}$ \\
$\mathrm{R}_{7.2}-30 \% \mathrm{GM}$ & $71.7 \mathrm{bA}$ & $67.3 \mathrm{bA}$ \\
$\mathrm{R}_{7.2}-20 \% \mathrm{GM}$ & $72.3 \mathrm{bA}$ & $70.0 \mathrm{bA}$ \\
$\mathrm{R}_{7.2}-$ No water & $77.3 \mathrm{bA}$ & $72.0 \mathrm{bA}$ \\
\hline
\end{tabular}

Within each developmental stage, means followed by the same capital letter on a line and by the same lowercase letter within a column are not significantly different $(\mathrm{P} \leq 0.05)$, as determined by the Scott-Knott test.
Under field conditions, Paiva-Aguero (1995) demonstrated that soybean seed with values of electrical conductivity in the soak water of up to $110 \mu \mathrm{S} \cdot \mathrm{cm}^{-1 \cdot g-1}$ can exhibit high field emergence, provided that the conditions are favourable for seed germination and seedling emergence. The disorganized membrane structure in cells of low-quality seed results in ion leakage from the cells that is detected by measurements of electrolytes present in the seed soaking water solution (Hampton et al., 1992). This fact was also pointed out in studies by Salisbury and Ross (1994) who reported that when the cells are not alive their membranes are considerably more permeable to solutes. Severe oxidative attacks may result in disturbed membrane organization with consequent loss of cellular compartmentation. Thus, desiccation tolerance is thought to depend on reduced free radical production and the accumulation of scavengers of these free radicals (Leprince et al., 1993). In this study, the least vigorous seed (Table 6) were those subjected to heat stress, with no water supply, at $\mathrm{R}_{6}$, suggesting that mechanisms mediating desiccation tolerance were not yet developed in these seed.

Table 7 shows the results of the weight of 100 seed, as a function of the temperature regimens and stages of development. It was observed that the lowest seed weight was obtained from seed subjected to the high temperature stress at the $\mathrm{R}_{6}$ stage, which differed statistically from those subjected to mild temperature. When the results between both stages of development were compared it was clear that at $\mathrm{R}_{7.2}$, seed were statistically heavier than at $\mathrm{R}_{6}$, although similar regarding heat stress. According to Ritchie et al. (1994), soybean seed reach their final size at $R_{6}$, but retention of such dry matter levels is largely determined by the environmental conditions.

TABLE 7. Mean values of weight of 100 seed (g) obtained from soybean plants subjected to high $\left(28^{\circ} \mathrm{C}\right.$ to $\left.36^{\circ} \mathrm{C}\right)$ and normal $\left(19^{\circ} \mathrm{C}\right.$ to $\left.26^{\circ} \mathrm{C}\right)$ temperatures at $\mathbf{R}_{6}$ and $R_{7.2}$.

\begin{tabular}{ccc}
\hline \multirow{2}{*}{ Temperatures } & \multicolumn{2}{c}{ Developmental stages } \\
\cline { 2 - 3 } & $\mathrm{R}_{6}$ & $\mathrm{R}_{7.2}$ \\
\hline High & $17.2 \mathrm{bB}$ & $20.5 \mathrm{aA}$ \\
Normal & $19.4 \mathrm{aB}$ & $21.1 \mathrm{aA}$ \\
\hline
\end{tabular}

Means followed by the same capital letter on a line and by the same lowercase letter within a column are not significantly different $(\mathrm{P} \leq 0.05)$, as determined by the Scott-Knott test. 
Table 8 shows the results of the weight of 100 soybean seed when subjected to different conditions of water supply at $\mathrm{R}_{6}$ and $\mathrm{R}_{7.2}$. It was observed that the control seed, at both developmental stages, did not differ statistically for this parameter. The greatest values of 100 -seed weight were obtained for seed from the $\mathrm{R}_{7.2}$ stage and no statistical differences were detected for seed subjected to all of the waterdeficit stresses imposed. At the $\mathrm{R}_{6}$ stage, seed subjected to the $30 \%$ GM condition did not differ statistically from those of the control condition, which was most probably due to the fact that such deficiency was considered to be moderate, which, according to Ouattar et al. (1987), is overcome by the plant with the reduction in seed number rather than seed weight.

TABLE 8. Mean values of weight of 100 seeds (g) obtained from soybean plants subjected to different conditions of soil water availability at $\mathbf{R}_{6}$ and $\mathbf{R}_{7.2^{\circ}}$

\begin{tabular}{ccc}
\hline \multirow{2}{*}{ Water levels } & \multicolumn{2}{c}{ Developmental stages } \\
\cline { 2 - 3 } & $\mathrm{R}_{6}$ & $\mathrm{R}_{7.2}$ \\
\hline Control & $19.6 \mathrm{aA}$ & $20.3 \mathrm{aA}$ \\
$30 \% \mathrm{GM}$ & $19.3 \mathrm{aB}$ & $21.5 \mathrm{aA}$ \\
$20 \% \mathrm{GM}$ & $18.0 \mathrm{bB}$ & $21.0 \mathrm{aA}$ \\
No water & $16.2 \mathrm{cB}$ & $20.4 \mathrm{aA}$ \\
\hline
\end{tabular}

Means followed by the same capital letter on a line and by the same lowercase letter within a column are not significantly different $(\mathrm{P} \leq 0.05)$, as determined by the Scott-Knott test.

The lowest values of 100 -seed weight were found as the water- and temperature-related stress conditions intensified, with significant differences between them (Tables 7 and 8). These results may be explained by studies in the literature on dry matter accumulation and translocation processes under water deficit, which lead to the production of seed of reduced size and weight and poor performance (França-Neto and Krzyzanowski, 1990; França-Neto et al. 1993; Marcos Filho, 2005).

\section{CONCLUSIONS}

In summary, imposing high temperature stress associated with no water supply at $\mathrm{R}_{6}$ results in a high level of expression of green seed, which reduces the weight of 100 seed. Intensive water stress at $\mathrm{R}_{7.2}$ associated with normal temperatures does not result in the occurrence of significant levels of green seed. The physiological quality of soybean seed is negatively affected by the incidence of green seed.

Additionally, it was concluded that exposing soybean plants in a controlled environment (phytotron) to high temperatures $\left(28^{\circ} \mathrm{C}\right.$ from 5:00 p.m. to $8: 00$ a.m.; $32^{\circ} \mathrm{C}$ from 8:00 to $10: 00$ a.m.; $36^{\circ} \mathrm{C}$ from 10:00 a.m. to 2:00 p.m.; and $32^{\circ} \mathrm{C}$ from 2:00 to 5:00 p.m.) with $20 \%$ GM water supply in the soil beginning at the $\mathrm{R}_{6}$ (full seed and green leaves) was a adequate method for screening soybean genotypes with regard to their tolerance and/or susceptibility to the expression of green seed.

\section{REFERÊNCES}

ASSOCIATION OF OFFICIAL SEED ANALYSTS. The seed vigor test committee. Seed vigour testing handbook. East Lasing, 1983. 88p. (To the Handbook on Seed Testing. Contribution, 32).

BOHNER, H. Green soybeans. 2002. Disponível em: < http://www.omafra.gov.on.ca/english/crops/field/news/ croptalk/2002/ct_1102a2.htm>. Acesso em: 12 July, 2005.

BRASIL. Ministério da Agricultura e Reforma Agrária. Secretaria Nacional de Defesa Agropecuária. Departamento Nacional de Produção Vegetal. Coordenação de Laboratório Vegetal. Regras para Análise de Sementes. Brasília, DF, 1992. $365 \mathrm{p}$.

CLAESSEN, M.E.C. (Org.). Manual de métodos de análise de solo. 2. ed. Rio de Janeiro: EMBRAPA-CNPS, 1997. 212p. (Embrapa-CNPS. Documentos, 1).

COSTA, N.P.; FRANÇA-NETO, J.B.; PEREIRA, J.E.; MESQUITA, C.M.; KRZYZANOWSKI, F. C.; HENNING, A. A. Efeito de sementes verdes na qualidade fisiológica de sementes de soja. Revista Brasileira de Sementes, v. 23, n. 2, p.102-107, 2001.

COSTA, N.P.; PEREIRA, L.A.G.; FRANÇA-NETO, J.B.; HENNING, A.A.; KRZYZANOWSKI, F.C. Zoneamento ecológico do estado do Paraná para produção de sementes de cultivares precoces de soja. Revista Brasileira de Sementes, v.16, n.1, p.12-19, 1994.

DORNBOS,D.L.;McDONALD,M.B. Massandcomposition of developing soybean seeds at five reproductive growth stages. Crop Science, v.25, n.3, p.624-630, 1986.

EGLI, D.B. Seed biology and the yield of grain crops. New York, CABI International, 1998. 178p.

FERREIRA, D.F. Análises estatísticas por meio do Sisvar para Windows versão 4.0. In: REUNIÃO DA REGIÃO 
BRASILEIRA DA SOCIEDADE INTERNACIONAL DE BIOMETRIA, 45., São Carlos, SP. Programas e resumos... São Carlos: UFScar, 2000. p.255-258.

FRANÇA-NETO, J. B.; KRZYZANOWSKI, F. C.; COSTA, N. P. O teste de tetrazólio em sementes de soja. Londrina: EMBRAPA-CNPSo, 1998. 72p. (EMBRAPACNPSo. Documentos, 116).

FRANÇA-NETO, J.B.; KRZYZANOWSKI, F.C. Sementes enrugadas: novo problema na soja. Londrina: EMBRAPACNPSo, 1990. 4p. (EMBRAPA-CNPSo. Comunicado Técnico, 46).

FRANÇA-NETO, J.B.; KRZYZANOWSKI, F.C.; HENNING, A.A.; COSTA, N.P. Tecnologia de produção de sementes. In: A cultura da soja no Brasil. Londrina: Embrapa Soja, 2000. 1CD-ROM.

FRANÇA-NETO, J.B.; KRZYZANOWSKI, F.C.; HENNING, A.A.; WEST, S.H.; MIRANDA, L.C. Soybean seed quality as affected by shriveling due to heat and drought stresses during seed filling. Seed Science and Technology, v.21, n.1, p.107-116, 1993.

FRANÇA-NETO, J.B.; PÁDUA, G.P.; CARVALHO, M.L. M. de, COSTA, O.; BRUMATTI, P.S.R.; KRZYZANOWSKI, F.C.; COSTA, N.P. da, HENNING, A.A.; SANCHES, D.P. Semente esverdeada de soja e sua qualidade fisiológica. Londrina: Embrapa Soja, 2005. 8 p. (Embrapa Soja. Circular Técnica, 38).

HAMPTON, J.G.; JOHNSTONE, K.A.; EUA-UMPON, V. Bulk conductivity test variables for mungbean, soybean and French bean seed lots. Seed Science and Technology, v.20, n.3, p.677-686, 1992.

HEATON, J.W.; MARANGONI, A.G. Chlorophyll degradation in processed foods and senescent plant tissues. Trends in Food Science and Technology, v.7, n.1, p.8-15, 1996.

LEPRINCE, O.; HENDRY, G.A.F.; McKERSIE, B.D. The mechanims of desiccation tolerance in developing seeds. Seed Science Research, v.3, n.3, p.231-246, 1993.

MARCOS FILHO, J. Fisiologia de sementes de plantas cultivadas. Piracicaba: FEALQ, 2005. 495 p.

McDONALD, Jr.; M.B. A review and evaluation of seed vigor tests. Proceedings of the Association of Official Seed Analysts, v.64, p.109-139, 1975.

OUATTAR, S.; JONES, R.J.; CROOKSTON, R.K. Effect of water deficit during grain filling on the pattern of maize kernel growth and development. Crop Science, v.27, n.4, p.726-730, 1987.

PAIVA-AGUERO, J.A. Correlação de condutividade elétrica e outros testes de vigor com emergência de plântulas de soja em campo. 1995. 92f. Dissertação (Mestrado em Produção e Tecnologia de Sementes) Faculdade de Ciências Agrárias e Veterinárias, Universidade Estadual de São Paulo, Jaboticabal.

R. Development Core Team. R: A language and environment for statistical computing. $\mathrm{R}$ Foundation for Statistical Computing, Vienna, Áustria. 2005, ISBN 3-900051-07-0. Disponível em: <http://www.R-project. org >. Acesso em: 25 set. 2009.

RITCHIE, S.W.; HANWAY, J.J.; THOMPSON, C.E.; BENSON, G.O. How a soybean plant develops. Ames: Iowa State University of Science and Technology: Cooperative extension, service, 1994. 20p. (Special Report, 53).

SALISBURY, F.B.; ROSS, C.W. Fisiología vegetal. 4. ed. México: Grupo Editorial Iberoamérica, 1994. 759p.

SINNECKER, P. Degradação da clorofila durante a maturação e secagem de sementes de soja. 2002. $103 \mathrm{f}$. Tese (Doutorado em Ciência dos Alimentos) - Faculdade de Ciências Farmacêuticas - Universidade de São Paulo, São Paulo, 2002.

SPEARS, J.F.; TEKRONY, D.M.; EGLI, D.B. Temperature during seed filling and soybean seed germination. Seed Science and Technology, v.25, n.2, p.233-244, 1997.

TAKAMYIA, K.; TSUCHIYA, T.; OHTA, H. Degradation pathway(s) of chlorophyll: what has gene cloning revealed? Trends Plant Science, v.5, n.10, p.426-431, 2000.

THEAJUMPOL, P. Effect of moisture content and curing temperature on seed color and quality of soybean. Thesis (MSc), Chiang Mai University 2002.

VIEIRA, R.D.; TEKRONY, D.M.; EGLI, D.B. Effect of drought stress on soybean seed germination and vigor. Journal of Seed Technology, v.15, n.1, p.12-21, 1991.

WOODSTOCK, L. W.; FURMAN, K.; LEFFLER, H. R. Relationship between weathering deterioration and germination, respiratory metabolism, and mineral leaching from cotton seeds. Crop Science, v.25, n.3, p.459-466, 1985.

ZORATO, M.F.; PESKE, S.T.; TAKEDA, C.; FRANÇANETO, J.B. Presença de sementes esverdeadas em soja e seus efeitos sobre seu potencial fisiológico. Revista Brasileira de Sementes, v.29, n.1, p.11-19, 2007. 